\title{
Problems and Challenges Faced by Students at Government High Schools in District Bajaur
}

\author{
* Dr. Ahmad Ali, Assistant Professor \\ ** Mr. Fazal Amin, MPhil Scholar \\ *** Ms. Sunbal, MPhil Scholar
}

\begin{abstract}
The objectives of this research study were to know about the challenges/ issues to government high schools in District Bajaur, which causes exclusion of students from learning environment. The nature of the study was quantitative and the data was collected through questionnaire in Tehsil Mamund. The study identified that students of the study area are facing some problems like shortage of classrooms, non-availability of furniture, lack of clean water, not well qualified teachers, elevated student-teacher ratios and in sufficient teaching resources that causes low quality education among students and frequently transmits little or no authentic learning. Moreover, nepotism, favoritism and bribes relation both in cash and kind badly affect the education system of the study area. From the research study it was concluded that rather than to bring harmony in society through education it brings dissonance and imbalances. In light of the study it is recommended to Government for giving a friendly attention to this historical big problem in locale in traditional as well as cultural context or giving golden handshake opportunities to the aged and low qualified teachers. The politician religious clergies and welfare organization are also requested to sensitize the people of the area for this holy purpose in friendly environment.
\end{abstract}

Keywords: Social Exclusion, Lack of Teachers, Lack of Supervision, Lack of Infrastructure. \section{Introduction}

Education plays a role, "like backbone", in the development of any country of the world. It is a well-known fact that any kind of growth and development in this world is because of education (Bergman and Muhammad, 1998). Education is actually the summation of the entire skills and knowledgeable experiences, which direct the attitude, behavior and determines of the both, the youngsters and the elders. This is education which brings positive

\footnotetext{
* Department of Sociology, AWKUM Email: ahmadalia@awkum.edu.pk

** Department of Sociology, AWKUM

*** Department of Sociology, AWKUM
} 
changes in individual' behavior, feelings and thoughts, due to getting these changes, the individuals become enable and capable to adjustment themselves in any sort the competitive societies (Quina, 1989). "Education for all was first slogan of Islam". The holy "Quran" and the sacred words (ahadees) of the Prophet Hazrat Muhammad (SAW) highly emphasized the knowledge. In addition to this, at numerous places in the Holy Quran, there are praises for those people, who learn themselves and teach the others. Another place in the holy "Quran", Allah says his prophet "Muhammad (SAW), "O Prophet ask them, can those, who know and those, who do not know ever be equal"?(Al Quran. Zumar: 39:9). According to Article 37 mentioned in the Constitution of 1973, it is the duty of the country to eliminate "illiteracy", and give necessary and free education to all people of Pakistan. The following are the main constraints for the achievement of primary education on international base i.e. financial limitations, Poverty, gender disparities mean, discrimination of males on females, imbalance of rural and urban in which, there are enough facilities as compare to rural areas, and lack of preference to education (UNICEF, 2007).

The ratification of Eighteenth Constitutional Amendment has brought momentous changes for the development and advancement of quality education at provincial and federal levels. Article 25-A, explains that education must be provide to all the children of five years to the age of sixteen years, that will be the responsibility of the state, to provide the children free of cost education with consideration of their justifiable and obligatory right. As a result of removal of synchronized law making list, the important areas of Education Policy i.e. Planning, Curriculum, Standard, and Islamic education have been grew-up worse to the province domain. In the get up 18th Constitutional amendment, the KPK government of Pakistan has ordained provincial rule for the supervision of course set up, with regards curriculum, Textbooks and continuation of quality of Education Act 2011(Government of Khyber Pakhtunkhwa, 2013). The common and prevalent educational system generally consists on various levels i.e. primary, middle, secondary, higher secondary, college and university (Farooq, 1993). According to UNESCO (2010), in Pakistan, secondary level refers to Grad 9 and 10, and 11-12 years of education labeled as higher secondary education.

It is an organized planning/efforts of developed and underdeveloped countries, to provide free education to all the citizens and to invest a huge amount of money according to their exist resources. Each and every state will provide free and low cost of education to their national people (Iqbal, 2012). According to the population Census of Pakistan in (1998) and the standard and social Measurement survey conducted in the year 2007, literacy rate is 
increasing in every year but the proper growth rate is not to the demand of era. The growth rate is very low as compare to the advance countries. The concerned statistic is given below. It increased from $43.9 \%$ to $55 \%$ in which the ratio of female with male is given respectively, female $32 \%$ \& Male $54.8 \%$ (1998), Female $42 \%$ and Male $67 \%$ (2007). In all the four provinces of Pakistan, Punjab has the greatest literacy rate i.e. 58\% as compare to the other provinces i.e. Sindh 55\%, KPK 47\% and Baluchistan has $42 \%$ (Pakistan Census Organization, 1998, Federal Bureau of Statistics, 2007;Ministry of Education, 1998 and Ministry of Finance, 2003). Lack of resources, inadequate provision of amenities and lake of standard trainings are the fundamental hurdles toward bestowing and expanding of quality education (Pakistan Economic Survey, 2012). From the time of freedom till now Pakistan has been facing so many problems in the education sector, due to so many reasons e.g. multicultural causes, education in different medium of instruction or languages, lack of nonavailability of resources and thus an improper and less utilization of these resources, and improper implementation techniques of educational policies.

The system of education is not up to the standard. It is very outdated and due to this poor educational setup, there are serious worries from all quarters of society. If educational system is running on its right and standard track, definitely society will grow up otherwise not. The schools are generally not doing well. Among these cases the secondary education system of is an important and life-threatening process. There are serious problems and issues in Pakistani educational system. After a long phase of militancy in Fata the high numbers of schools were being destroyed in Bajaur agency. Militancy and military operations affects the schools in the area so badly. The territory was primarily deprived of education as a result of, local khan/malik system. And then came the turn of Italianization and militancy which destroyed the emerging trend of education haphazardly. The current study is aimed to investigate and analyze the sociological factors and problems that have been faced by the schools of Bajaur Agency.

\section{Literature Review}

According to Islamic point of view, education is an instrument for bringing positive and optimistic changes in an individual's attitudes and behavior. These changes of individual will make a balance and a sound Islamic society by giving respect to others, in response getting respects from them (Govt. of Pakistan, 1998). According to constitution of Pakistan, Education is being kept on top rank among fundamental rights of the citizens of the country. It is a commitment of the government of Pakistan to provide education to every citizen of 
Pakistan.(Mustafa G, 2012). The constitution of Pakistan 1973 acknowledged that, the Pakistani government will eliminate and will raise the literacy for all, up to the desire and significant level, within the possible short period of time. Among these acknowledgments, education is mad compulsory and free of cost of to the secondary level. The mentioned articleno "37-B" explains that the eradication of illiteracy and provision of free education up to secondary level will be the responsibility of the state, within the fix and possible time (Article 37-B, Constitution of Pakistan). According to the report of UNESCO ( 2005), Pakistan kept its position on 102, out of 130 in the world for allocating $2.3 \%$ of the total GDP. According to the need and demand of education the concerned budget is not enough. The fundamental hurdles in transmitting and intensifying education are: Deficiency of capitals and inadequate stipulation of amenities and trainings (Pakistan Economic Survey 2012, 137pp).

\section{Lack of Basic Infrastructure}

The excellence of school buildings has also been associated to student actions, Including damaging, absenteeism, suspensions, disciplinary incidents, aggression, and smoking (Schneider, 2002).Government does not give any inhabited housing to school teachers. Therefore, the teachers who are posted in far-flung areas are not able to carry out their duties, due to non-availability of inhabited conveniences. The teachers, who are not with their families, will not be able to perform effectively with regards teaching (Government of Punjab, 2004). Due to no official accommodation problems the teachers are not able to perform their duty in its good manner, because for best teaching there must be mental satisfaction with regards the above things which they are missing them already (Hussain, 2001). The teachers face many problems like, lack of teaching and learning aids, lack of suitable environment, no proper buildings etc. Some schools even do not have indispensable aids such as boards and the text books. Some schools do not have classrooms for students and library for students to use it, in their spare time. The missing of playgrounds, which are very necessary for the physical development of the students (Qureshi, 2002). The concerned situations create more problems for the teachers, because sometimes the students demand for the above things and if they are not present to them, then even they don't take any interest in their study. On the other side these all Teachers are expected and compelled to cover the courses well, in the given time. In response the teachers become fail to provide the meaningful learning environment to their students (Hussain, 2001). 


\section{Lack of Physical and Learning Resources}

In most of the high schools physical and learning resources are very much limited, especially for attaining classes; proper classrooms are not available as well as learning resources libraries, and laboratories (Qureshi, 2002). Due to the public sector of Pakistan quality of education doesn't still exist in the society. There are various problems behind this which may be called the big hurdles in the development of education. These are; lack of classrooms which support the teachers and provide them suitable environment during teaching, lack of able and trained teachers, poor quality of textbooks and learning aids, lack of proper supervision for the students, lack of continue checking and periodical evaluation for the better outcomes of students, lack of proper management on behalf of government and public sectors (World Bank, "Third Punjab Education” 2006).

\section{Lack of Teachers}

Teaching is measured the most honorable profession in all the societies of the world. Teachers are maybe the most important part of an education system (Rehman, 2002). How well they educate, depends on enthusiasm, qualification, skill, guidance, ability and a multitude of other factors, not the slightest of these being the environment and management structures within which they carry out their role. Poor education is due to lack of quality teachers, which play a key role in the development of educational system. Unfortunately, the teachers of Pakistan are missing the best qualities, which should be adopted for the better teaching performance (Memon, 2007).The final learning outcomes planned in the National Curriculum are to a certain extent determined, requiring teachers to take upall-inclusive vision of pedagogies and employ in practices premised on constructivist viewpoint of learning which emphasizes centrality of students in the learning process (Fosnot, 2005).Shah and Inamullah (2012) found from their studies that, congested classes could have a straight impact on students' learning. They not only affected students' performance but the teachers had to face different problems such as discipline problem, poor health environment, lack of attention from the students, stress and tension for the teacher, behavioral problems and this congested situation of the class, make an opportunity for the high drop-out rate among the students. Unluckily, in a lot of government and private schools in Pakistan, teachers generally fail to inspire and care for the significant abilities of students. In consequences after passing Grad 10 most of the students fails to build any relation with the subject (Government of Pakistan, 2009). Teachers try to convey the facts to the students that are ordered in 
textbook, assess students' education through getting them to identify or apply the rules in a standard way (Amirali \& Halai, 2010; Mohammad, 2002).

\section{Aim and Methodology}

The main objectives of the existing study were to find out the problem of infrastructure in government high schools of Bajaur Agency and secondly to know about the lack of teachers in government high schools of Bajaur Agency. The said objectives were based on and measured through hypothesis i.e. Lack of Infrastructure in Government schools lead to decrease the quality of government high schools and overcrowded classrooms and lack of teacher's interest leads to increase the dissatisfaction level of the students.

Methodology refers to the rules, procedures, guidelines, with the help of this a researcher conducting a particular research activity (Daraz, 2012). The main concern of this is to find out the problems faced by the government high schools. This research activity is conducted in Bajaur agency, and further delimited to Tehsil Mamund, in order to delimit the area and for easiness of the researcher where the problems in government schools founded. The total population of Tehsil Mamund is estimated 80, 000 (IVAP, 2012), however the data has been collected from students. Among the total students 1325, due to time and resource limitation the researcher has been only taken 50 respondents using simple purposive sampling. The data was collected through interview schedule and was analyzed through frequency distribution tables.

\section{Results and Discussions}

The situation of Government schools all over the country and worth of education being imparted, are going from bad to worse, day by day. Government and the concerned Education department are not interested, to provide the fundamental facilities to all the educational institutions. About the desirable facilities in government high schools, question asked from the respondents. Out of total respondents i.e. 50 (100\%), 14(28) of the respondents were satisfied from the facilities provided by their schools, while 36(72\%) of the respondents were not satisfied from the facilities.

In case of dissatisfaction, the respondents divided into four categories. Among 50 $(100 \%), 7(19 \%)$ of the responses were in favor of category A. similarly $7(19 \%)$ of the respondents' responses in category B. $22(62 \%)$ of the participants' responses in the third category. The above discussion shows that high number of respondents was not satisfied from 
the facilities provided by the schools, and in the second category most number of the participants agreed on category $\mathrm{C}$ (lack of number of teachers).

\section{Table -1: Facilities in School}

\begin{tabular}{lccccccc}
\hline Statement & Frequency & Percentage & \multicolumn{5}{c}{ If no, then specify } \\
& & & A & B & C & D & Total \\
\hline Yes & 14 & 28 & $7(19 \%)$ & $7(19 \%)$ & $22(62 \%)$ & \\
No & 36 & 72 & & & & \\
Total & $\mathbf{5 0}$ & $\mathbf{1 0 0}$ & $\mathbf{7}$ & $\mathbf{7}$ & $\mathbf{2 2}$ & $\mathbf{3 6 ( 1 0 0 \% )}$ \\
\hline
\end{tabular}

Denotation F: Frequency P: Percent or \% A: Lack Infrastructure Facilities C: Lack of learning resources D: Lack of Number of teachers E: Any other

\section{Explanation}

The standard of education is also the individuals of the society. The quality of education is related with the quality of facilities provided by educational institutions in the shape of infrastructure or learning resources. The above table shows that most of the respondents were not in favor of facilities provided by their schools. Among the total respondents i.e. 50 $(100 \%), 10(20 \%)$ of the respondents responses in category A, while $40(80 \%)$, of the respondents responses in category $\mathrm{B}$.

In case of no) the responses of participants divided into four categories. Among the total respondents i.e.50 (100\%), 14(35\%) of the respondents agreed on category A, while 6 $(15 \%)$ of the respondents pick the category B. similarly $6(15 \%)$ of the respondents pick the category C, and 14 (35\%) of the respondents were in favor of category D. The discussion shows that most of the respondents were not satisfied from the infrastructure facilities in their school. The discussion also shows that the respondents were not satisfied from the classrooms and availability of chairs in their schools.

\section{Table -2: Infrastructure Facilities in Schools}

\begin{tabular}{|c|c|c|c|c|c|c|c|}
\hline \multirow[t]{2}{*}{ Statement } & \multirow[t]{2}{*}{ Frequency } & \multirow[t]{2}{*}{ Percentage } & \multicolumn{5}{|c|}{ If no, then specify } \\
\hline & & & $\mathbf{A}$ & B & $\mathbf{C}$ & D & Total \\
\hline Yes & 10 & 20 & $14(35 \%)$ & $6(15 \%)$ & $6(15 \%)$ & $14(35 \%)$ & \\
\hline No & 40 & 80 & & & & & \\
\hline Total & 50 & 100 & 14 & 6 & 6 & 14 & $40(100 \%)$ \\
\hline
\end{tabular}




\section{Explanation}

Basically teachers are thought to be instruments of change in the society. In the field of education, teacher play a key role with regards his/her best performance and crucial input for the advancement of his/her students. But the dilemma is that, schools facing the problem of lack of teachers. Among the total students i.e. 50(100\%), $46(92 \%)$ of the respondents choose that they are facing lack of teachers in their schools, while $4(8 \%)$ of the respondents not agreed the statement. Further the responses of participants is divided into four categories A, B, C, D.

In case of no, among the total number of respondents, $31(67 \%)$ of the respondents choose the category $\mathrm{A}$, and $8(17 \%)$ of the respondents pick the category B. similarly the 7 $(15 \%)$ of respondents choose the option $\mathrm{C}$. The above discussion shows that large number of schools facing the lack of teacher's problem. Just less number of students in favor of number of teachers in their schools. In case of no, high number of students choose the category A, (teachers are not equal to our strength).

\section{Table-3: Number of Teachers in Schools}

\begin{tabular}{|c|c|c|c|c|c|c|c|}
\hline \multirow[t]{2}{*}{ Statement } & \multirow[t]{2}{*}{ Frequency } & \multirow[t]{2}{*}{ Percentage } & \multicolumn{5}{|c|}{ If yes, then specify } \\
\hline & & & $\mathbf{A}$ & B & $\mathbf{C}$ & D & Total \\
\hline Yes & 46 & 92 & $31(67.3 \%)$ & $8(17.3 \%)$ & $7(15.2)$ & & \\
\hline No & 4 & 8 & & & & & \\
\hline Total & 50 & 100 & 31 & 8 & 7 & & $46(100 \%)$ \\
\hline
\end{tabular}

Denotation F: Frequency P: Percent or $\%$ A: Teachers are not equals to our school strength. B: The qualified staff is not available in our school .C: Teachers are not taking classes regularly .D: Any other

\section{Explanation}

Teachers are maybe the most significant part of an education system. The best teaching of a teacher depends on his/her qualification, inspiration, experiences, preparation, skills and a crowd of other factors, not the least of these being the surroundings and administrative structures within, which they carry out their role. Among the total students i.e. 50(100\%), 24 $(48 \%)$, of the respondent pick the category A, and 26 (52\%), of the respondents choose the category B. 
Further in case of no, the respondents divided into four categories. Among the total respondents, the 14(54\%), of respondents choose the option A, and 5 (19\%) of the respondents pick the option B. similarly $7(27 \%)$ of the responses were in favor of $\mathrm{C}$. The discussion shows that most of the schools facing lack of qualified staff in their schools. In case of no, most students pick the option A that is the teachers are only graduated.

Table-4: Qualified Staff in Schools

\begin{tabular}{|c|c|c|c|c|c|c|c|}
\hline \multirow[t]{2}{*}{ Statement } & \multirow[t]{2}{*}{ Frequency } & \multirow[t]{2}{*}{ Percentage } & \multicolumn{5}{|c|}{ If no, then specify } \\
\hline & & & $\mathbf{A}$ & B & C & D & Total \\
\hline Yes & 24 & 48 & $14(54 \%)$ & $5(19 \%)$ & $7(27 \%)$ & & \\
\hline No & 26 & 52 & & & & & \\
\hline Total & 50 & 100 & 14 & 5 & 7 & & $26(100 \%)$ \\
\hline
\end{tabular}

Denotation F: Frequency $\quad$ P: Percent or $\% \quad$ A: The teachers are only graduated B: The teachers follow the traditional method of teaching. C: The teachers cannot maintains classroom discipline D: Any other

\section{Explanation}

Teacher plays a very important and vital role while performing and fulfilling the desirable goals of quality education. Due to the public sector of Pakistan quality of education doesn't still exist in the society. There are various problems behind this which may be called the big hurdles in the development of education. These are; lack of classrooms which support the teachers and provide them suitable environment during teaching, lack of able and trained teachers, poor quality of textbooks and learning aids, lack of proper supervision for the students, lack of continue checking and periodical evaluation for the better outcomes of students, lack of proper management on behalf of government and public sectors. (Are you satisfied from your school teachers?) this question is divided into two categories. Among the total students i.e. $50(100 \%), 24$ of $(48 \%)$ respondents belong to the category Yes, and 26 $(52 \%)$ respondents responded in the category No.

Further in case of No, the responses divided into four categories. Among the total participants $11(42 \%)$ of respondents pick the category A, and $13(50 \%)$ of the respondents choose the category B. Similarly $2(8 \%)$ respondents pick the category C. The above table shows that the students are not satisfied from the school teachers. However a good number of 
respondents were satisfied from their school teachers. In case of No, most of the respondents pick the category B (they are mostly absent from schools).

Table-5: Student Satisfaction level from School Teachers

\begin{tabular}{|c|c|c|c|c|c|c|c|}
\hline \multirow[t]{2}{*}{ Statement } & \multirow[t]{2}{*}{ Frequency } & \multirow[t]{2}{*}{ Percentage } & \multicolumn{5}{|c|}{ If no, then specify } \\
\hline & & & $\mathbf{A}$ & B & $\mathbf{C}$ & $\mathbf{D}$ & Total \\
\hline Yes & 24 & 48 & $11(42 \%)$ & $13(50 \%)$ & $2(8 \%)$ & & \\
\hline No & 26 & 52 & & & & & \\
\hline Total & 50 & 100 & 11 & 13 & 2 & & $26(100 \%)$ \\
\hline \multicolumn{8}{|c|}{ Denotation F: Frequency P: Percent or \%A: They are not selected on merit basis B: They } \\
\hline $\begin{array}{l}\text { are mostly a } \\
\text { other }\end{array}$ & ent from sch & $\mathrm{C}:$ & ley take no & nterest in & dent's & duc & ion D: Any \\
\hline
\end{tabular}

\section{Conclusion and Recommendations}

This is education which provides a base for socio-economic development of any country. An educational system of deprived quality may be one of the central reasons, due to which a question arises here, why poor countries do not grow as compare to the rich or advanced ones? Education system of Pakistan is facing new challenges of the modern society. It has yet to be developed at equivalence with other rising countries in the region. District Bajaur is comparatively one of the rural areas of Pakistan, having patriarchal structure of family. Due to lack of education, they are conservative in their customs and traditions; therefore ratio of education is very much low and not accessible. The people of the area were aware about the importance of education, that education brings change and development in the society. The people argued that their schools facing the problems of infrastructure, administration and lack of teachers. The improvement of secondary school infrastructure is the main problem to schools in the area, whether in the shape of less number of classrooms, less availability of furniture or lack of clean water. The low level of qualification for the teachers, high ratios of students as compare to teachers, inadequate teaching aids and traditional teaching methods are the major causes of which titled the low quality of education for the country, that often transmits little or no concrete learning. The study also concluded that teachers are overburdened with taking more classes, due to shortage of teaching staff in the schools. Due to lack of fundamental resources in schools, the teachers are helpless while he/she may be a qualified person, without the fundamental teaching aids, a teacher couldn't imagines for the 
quality performance of teaching. No proper training being arranged for the teachers to update the teachers and to improve their teaching skills by utilizing these trainings. On the basis of conclusion of the study the following recommendations are proposed.

\section{Provision of Facilities}

The provision of basic facilities should be provided for the better performance of both the teacher and student. The concerned facilities and teaching aids should be provided according to their requirements. Proper furniture should be provided, that the students may get a suitable and relaxed environment for carryout their study. Proper and modern based trainings should be provided to the in-serviced teachers, that to get the modern teaching methods, skills and utilizing of modern electronic devices.

\section{Provision of Qualified Teaching Staff}

The teachers' selection should be totally based on merit. Able and qualified teacher can perfume his/her teaching duty very well as compare to low level educated teacher. After selecting the qualifying teachers, the concerned teachers should have to provide the immediate trainings according to the demand of psychological fulfillment of the students. Due to this type of trainings the teachers will get knowledge about the mental level of their students, and they will teach them according to their mental level. The government should have to increase their salary and provide the basic facilities to all the teachers; due to taking this good step, the teachers will have dignity and status in the local society. Other people will also show their interest to join education department as their professions.

\section{Increase in Number of Schools}

Schools are less in numbers, while the population ratio of students is very high. The Government should have to launch a survey and establish the maximum number of schools according to the demand of students' population.

\section{Increase in Budget Allocation to Schools}

For the provision of quality buildings, sufficient classrooms and relevant number of teachers, there should be the sufficient budgetary allocation in the annual financial budget. According to the report of UNICEF (2007) the budget allocated in Pakistan for education is not enough, so, the Pakistani government should have to allocate the sufficient budget in the national GDP. This will provide the system with resources to take fresh breath of life.

\section{References}

Government of Khyber Pakhtunkhwa (2013). Annual Status of Education Report 2012: Khyber Pakhtunkhwa and FATA. Peshawar: Government of Khyber Pakhtunkhwa 
The state of the world's children 2008: child survival", UNICEF (2007).

M. Iqbal Chaudhry, Pakistani society: a sociological perspective. 4th rev. and enl. ed. (Lahore: Aziz Publishers, 1980)

Right to Free and Compulsory Education in Pakistan: Enforcement of Article 25-A of the Constitution of Pakistan. (June 2011). Islamabad: Pakistan Institute of Legislative Development and Transparency.

Ministry of Education, National Education Census 2005- Pakistan (Islamabad: Government of Pakistan, 2006).

Bregman, J. \& Muhammad, N. (1998). Primary and secondary education structural issues.(pp. 23-31) Islamabad: Jan Publications

Quina, J. (1989). Effective Secondary Teaching. New York: Harper \& Row Publishers.

Iqbal M. H. 2012 Teacher Self-Efficacy as a Function of Student Engagement, Instructional Strategies and Classroom Management. Pakistan Journal of Social \& Clinical Psychology Volume 9 issue 3

Government of Pakistan, "National Education Policy 1998-2010" Ministry of Education, Islamabad (1998).

Mustafa Ghulam, 2012. Educational policy analysis report of Khyber Pakhtunkhwa, UNESCO, Pakistan

UNESCO. (2005). Primary education for all children. Paris: UNESCO.

Secondary education regional information base: country profile Pakistan. Bangkok: UNESCO Bangkok, 2010. 20 pp.

Pakistan Economic Survey 2011-2012.

Schneider, M. (2002). Do school facilities affect academic outcomes? National clearinghouse for educational facilities, 1-24. Retrieved Oct 10, 2014, from https://www.azdeq.gov/ceh/download/greenschool.pdf

Government of Punjab (2004). Standard Manual, Elementary, Secondary and Higher Secondary Schools. Education Department, Punjab, Lahore, Pakistan, pp. 10

Hussain, S.A. (2001). Education in Pakistan. Allama Iqbal Open University. Islamabad,Pakistan pp.1-12

Qureshi, S. (2002). Decentralization to district level. Ministry of Education, Islamabad, Pakistan. pp.31-40

World Bank (2006). Simplified Implementation Completion Report. Second Development Policy Credit for the Government of Punjab Province. Report No. 35465. 
Rehman, J.U (2002). Devolution and decentralization: Identification of progress in implementation in education. Ministry of Education. pp. 233-240

Memon, G.R (2007). Education in Pakistan: The Key Issues, Problems and The New Challenges. Journal of Management and Social Sciences Vol. 3, No. 1, (Spring 2007) 47-55

Govt. of Pakistan (2009). National Education Policy. Islamabad: Ministry of Education

Amirali, M \& Halai, A (2010). Teachers' knowledge about the nature of mathematics: A Survey of secondary school teachers in Karachi, Pakistan. Bulletin of Education and Research, 32 (2), 45-61.

Fosnot, C. T. (2005). Constructivism revisited: Implications and reflections. In C.T. Fosnot (Ed.). Constructivism: Theory, perspective and practice (2 $2^{\text {nd }}$ Edition) (pp. 276-292). New York: Teachers College Press.

Shah, J., \& Inamullah, H.M. (2012). Overcrowded classrooms: A serious problem for teachers. The Journal of Educational Strategies, 5(1), 772-789. 